\title{
REHABILITATION OF PUBLIC SQUARES CONNECTED TO THE WORLD HERITAGE AREAS OF PÉCS
}

\author{
Kinga Éva PACZOLAI ${ }^{1}$, Balázs KÓSA², Renáta NÉMETH-SZIGETI ${ }^{3}$ \\ ${ }^{1}$ University of Pécs, Faculty of Engineering and Information Technology, Department of Architecture and \\ Urban Planning, paczolaik@gmail.com \\ ${ }^{2}$ University of Pécs, Faculty of Engineering and Information Technology, Department of Visual Studies, \\ kosa.balazs@mik.pte.hu \\ ${ }^{3}$ University of Pécs, Faculty of Engineering and Information Technology, Department of Engineering Studies, \\ reni.szigeti@gmail.com
}

\begin{abstract}
The World Heritage Square at Pécs is to be constructed in the framework of a program dedicated to developing the locations of the World Heritage. The aim is to rehabilitate the squares belonging to the World Heritage in the hope of increasing the attendance on a conceptual thinking. The study focuses on the marked areas with the purpose of connecting the Castle Wall and its walkway. The rehabilitation even extends to redesign the area in front of the Old Christian Mausoleum.
\end{abstract}

Keywords: World Heritage, walkway, Barbakán, Pécs, public square.

\section{The Conception of the Castle Wall Walkway}

To visit the sights of the World Heritage Quarter, it is recommended to construct a well-established and interconnected tourist route as a complete travel plan which can be optionally extended with a walk by the castle wall along the historical educational trail which is to be built on the Northern Castle Wall Walkway.

The castle wall walkway starts from the garden situated north-east from the Dome Stonework Museum. This site holds excellent qualities, however the rehabilitation of the greenery and effective developments are inevitable. The hedge maze in the middle of the garden is in a bad condition, it is questionable whether the plants composing the hedge can be saved at all. The construction in itself however is valuable so we have created a space construction while taking the maze into consideration. The maze will be reconstructed using crumb rubber so children can play safely and as they please. The peaceful environment is also suitable for organizing events. In order to utilize this, a mobile stage with an auditorium will be erected. The stage will be placed in the south-western corner of the garden so the audience will have enough space while the monumental shape of the Dome reaching to the sky sets extraordinary scenery.

In order for the walkway to be continuous, the garden and the already renovated part of the walkway stretching at the north of the Medieval University have to be connected. A parapet walkway will be attached to the eastern side of the first bastion to reach the upper level of the tower. The first information point will be found in the area of the bastion and the parapet walkway. The question of covering has been discussed thoroughly and finally metal covering was chosen, thus perforated composite board will be used.

Traveling further, the second bastion belongs to the already renovated part of the walkway. It will hold the next information point during guided tours. A steel platform will be built above the already existing wooden stairs so the tower can also serve as a lookout point. Bastion No.3 will also be 
one of the information points, there is no need for changes here except for the development of the information point and general lighting.

In its current state, the north-western castle wall walkway is not finished yet. It is unavoidable to clean the area and to tend to the greenery as part of the developments. The restoration of the walls of Bishop's castle is in progress but because of corrosion and the destructive effect of the plants, the thorough cleaning and renovating of the outer castle wall will also be necessary. Similar to the already renovated part of the walkway, the path will be covered with cobbles after landscaping. In this way, the fourth bastion can also be used as a lookout point.

Guests will be guided from the north-western castle wall walkway through a bridge over Barbakán ditch to Barbakán square. The bridge will be both a physical and historical connection. The stainless steel trussing covered with perforated high gloss aluminium composite board will loom like a mirage among the chestnut trees. It

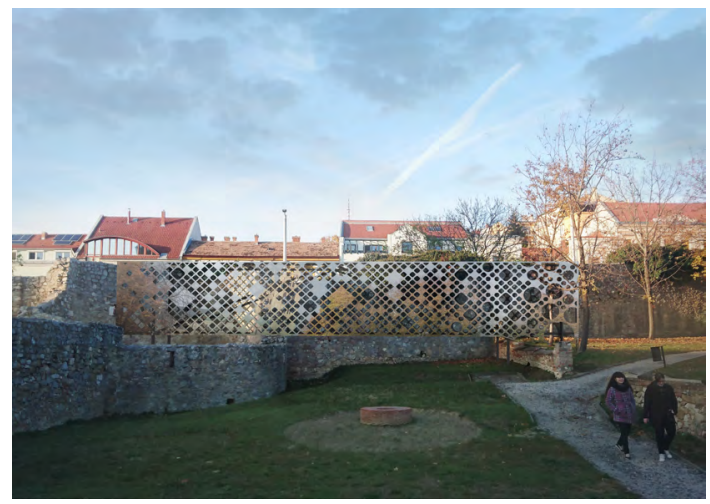

Figure 1. Pécs, I. Conception of the parapet walkway to bastion

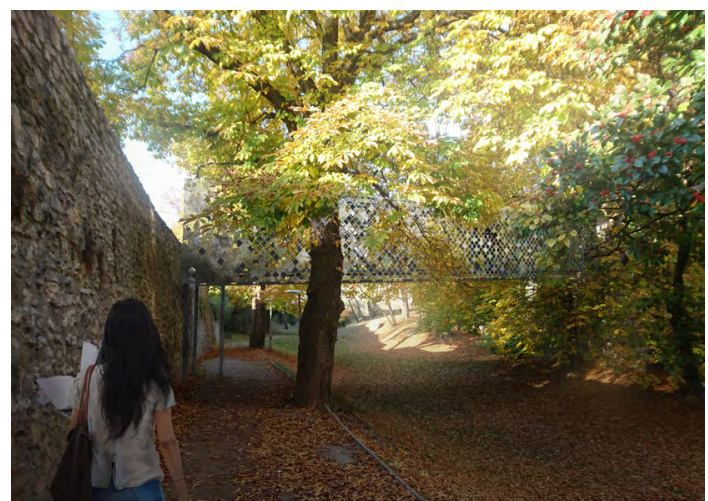

Figure 2. Conception of the bridge over Barbakán ditch will be similar in its appearance to bastion No.1 and will mirror the symbolic shapes of the parapet walkway, framing the target areas of development. Walking over the ditch, we arrive at the fifth tower. Barbakán Bastion and its close surroundings have already been renovated thanks to a previous investment. It will be necessary to reconstruct the passageway of Barbakán garden with a more spectacular connecting solution. The rehabilitation of the garden's green space, establishing suitable general lighting and the change of paving are inevitable.

\section{The Old Christian Mausoleum}

The world heritage walk would not be complete without mentioning the Old Christian Mausoleum (its entrance can be accessed through Szent István square). The two-story building was founded in 1975 during the repair of the waterfall which was terraced until then. The ground floor was a place of remembrance while the dead were buried in the burial chamber underneath [1]. It was probably constructed in the 70 s and 80 s of the 4 th century in at least two building periods, both of them affecting the burial chamber [2]. Its expansion and the placing of two additional sarcophagi occurred during the second building period.

The ruins of the cemetery chapel and the burial chamber hidden below can easily be overlooked while descending the sloping walkway. In this area, it is especially important to grab the attention of visitors. In order to achieve this and to lure guests down, the shaping of space and the construction of a suitable reception building will be necessary.

Getting down to the underground area of the Old Christian Mausoleum, built for the purpose of protecting the burial chambers, is ensured by a metal sluice-system which opens to the stairway. The sluice gives no possibility of keeping itself constantly open as well as shutting the suitable forefront of the Museum out. The outdated electrical and engineering protecting building cannot satisfy the functioning of the building sufficiently. The existing entrance is unreasonably undercover, seeming as a mine. The form of the entrance is even more highlighted by the escarpment in the southern part filled with shrubs.

In the framework of the rehabilitation program we have constructed a new entrance building to the Mausoleum, preserving the existing stairway, however, disassembling the sluice. A semicircular mass, matching with the walling will be placed 


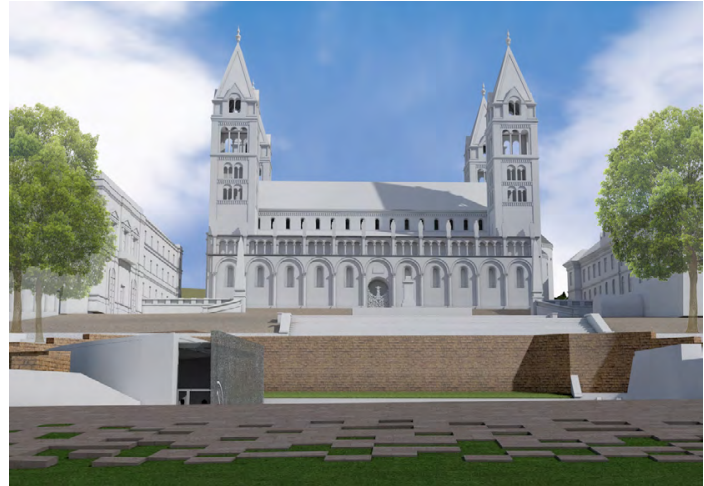

Figure 3. Pécs, Conception of the Old Christian Mausoleum into the location of the western supporting wall providing the chance of forming the entrance and the ticket office. The entrance building can be divided into three mass sectors. The western side is a white semi-circular shaped, low tilt angled mass and will have white covering with sheet-metal; the entrance glass-strip will be covered with a glass roof; and the eastern frontage wall will be formed from pixelconcrete.

The ruins below and above the ground need to be restored. Along with the project, the renovation of the building's engineering and electrical system is also necessary in order to ensure the building's proper functioning as well as refur-
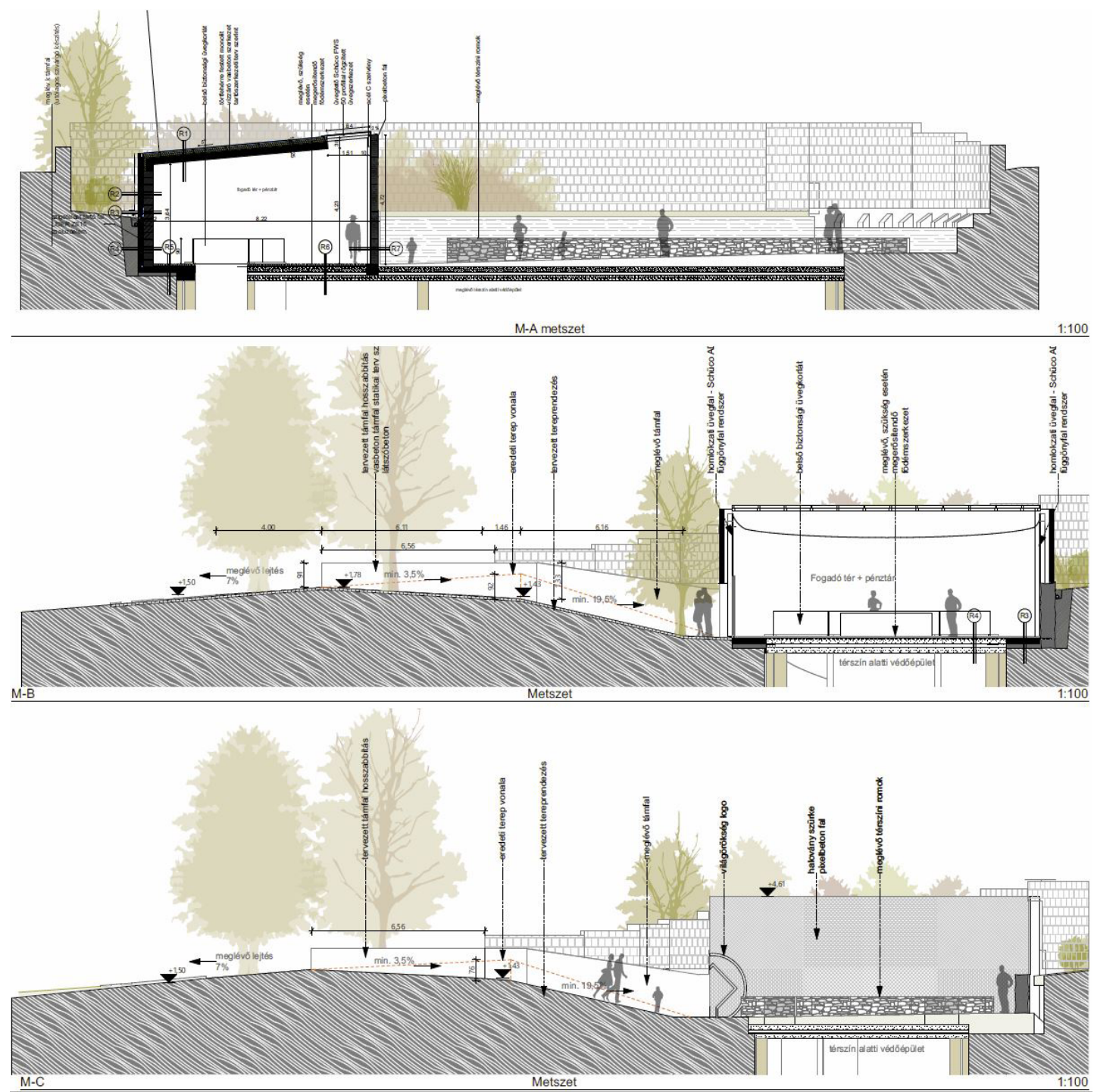

Figure 4. Pécs, Conception of the Old Christian Mausoleum 
bishing the lighting and air conditioning for the chambers.

A landscaping will be executed along the southern escarpment. The existing high-pitched escarpment will be flattened to open the chambers of the Mausoleum's surface and opening the entrance towards Szent István square. As a result of the planned restructuring of the escarpment, it will no longer have the look of a mine, meanwhile making the square approachable. The covering of the square contributes to holding various events. The East-Western permeability is not to be harmed.

\section{Conclusion}

The areas of the Dome square - Szent István square - Apáca square - Széchényi square - Káptalan Street are accentuated parts in the development of the city's tourism and archaeology. In the current situation, the attractions of the city are located fractionally making it circumstantial to reach them. The aim is to display the antique collections and heritage from various eras with modern technology.

The intention has already started at some locations, which we aim to further continue, to establish a complete travel plan while observing the rules of historic preservation.

Local interests and entertainment opportunities need to be satisfied, therefore besides making these monuments more accessible, another aim of the program is to form these locations suitable for longer staying. The newly constructed event spaces could serve as places for programs, concerts, adding to the city's social development in the hope of using these World Heritage locations as a real "World Heritage Square".

\section{References}

[1] A. Bozóky: Világörökségi helyszínek - Pécs. Múltunk tükre, jövőnk gyökere. Zsolnay Örökségkezelő Nonprofit Kft., Pécs, 2013. 1-23.

[2] Cs. Pozsárkó, Zs. Tóth: Pécs a római korban Vezető a pécsi világörökség helyszíneihez. Zsolnay Örökségkezelő Nonprofit Kft., Pécs, 2011. 6-9. 